研

究

\title{
焼結接合法によるフェライト部品の作製
}

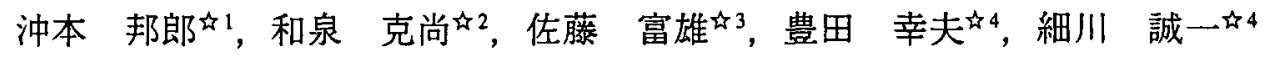 \\ 中1 摄南大学, $=572-8508$ 寝屋川市池田中町 17-8. 摄南大学大学院工学研究科, $\bar{T}$ 572-8508 寝屋川市池田中町 17-8. \\ 中 3 九州工業技術研究所, $\bar{T}$ 841-0052 佐賀県鳥栖市宿町. 的住友特殊金属侏， $\overline{\mathbf{T}}$ 618-8555大阪府三島郡島本町江川 2-15-17.
}

\section{Sinter Joining Properties of Ferrite Magnets}

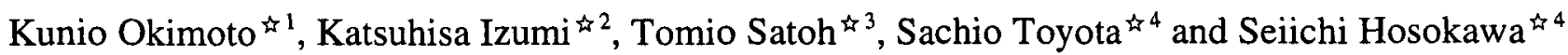 \\ ${ }^{1}$ Setsunan University, 17-8 Ikeda-nakamachi, Neyagawa 572-8508. "2 Graduate School,Setsunan University, 17-8 Ikeda-nakamachi, \\ Neyagawa 572-8508. ${ }^{3}$ Kyushu National Industrial Research Institute, Shuku-machi, Tosu 841-0052. ${ }^{4}$ Sumitomo Special Metals Co.Ltd., \\ 2-15-17 Egawa Simamoto-cho Mishima-gun, Osaka 618-8555.
}

Received March 6, 1998

\section{SYNOPSIS}

For the purpose of fabricating ferrite part with a complicated shape which has different orientation of the ferrite, joining of pre-formed green compacts was studied, and in particular the feasibility of combined sinter joining method was investigated. As the first step, two simple compacts of disk and ring shape have been individually produced under the non-magnetic field condition. The two compacts was assembled into a unit and then sintered at $1150^{\circ} \mathrm{C}$ and $1225^{\circ} \mathrm{C}$. Effect of addition agent and sintering temperature on the joint strength of the the sintered compacts has been studied. The joint strength of the compacts sintered at $1225^{\circ} \mathrm{C}$ was about 2 times of that of the compacts sintered at $1150^{\circ} \mathrm{C}$. The maximum joint strength was obtained when an inner disk with 0.75 mass $\% \mathrm{CaO}$ and an outer ring with 0.75 mass $\% \mathrm{CuO}$ was joined at sintering temperature of $1225^{\circ} \mathrm{C}$.

KEY WORDS

ferrite, sinter joining, sintered magnet, orientation, alignment, powder metallurgy, joint strength.

\section{1 緒言}

フェライト焼結磁石の金型成形法は,ニアネットシェイプで 安価に，かつ大量に永久磁石を作製することができる，しか し, 通常の金型成形法の場合, 部品形状によっては一工程で意 図した形状が得られず,別々に作製した部品を接合して一つの 部品としたり，粉末射出成形法"局いたりする必要がある.

また，最近ではFig.1のように，部品の部位によって配向の 向きが異なる磁性体が,例えば制御モー夕の駆動と回転速度の 検出に用いられている.このような部品を作製する手段として は, 複雑な向きの配向磁界の中で射出成形”を行ったり，個々 に配向成形した焼結体を接着する方法が考えられている。しか し, 前者は配向・成形のための設備が複雑で, 後者は接着の工 程に余計な手間がかかる.そこで著者らは, 複雑な配向と入り 組んだ形状を持ったフェライト磁性体を比較的容易に作製する 手段として,予備成形した単純な形状の圧粉体を組み立てた後 に焼結接合する方法 3 -7)に着目した。

この焼結接合法を適用しようとする場合,最も問題となるの は接合強度である、そこで, 本研究では Fig.1のような配向方
向の異なる磁性体を作製するための第一段階として，Fig.2の ような円柱形のインナーとリング形のアウターからなる無配向 の接合体のせん断強度試験を行い, 接合強度の点からこの手法 の可能性について検討した。また，焼結体の磁気特性について も測定を行った。

\section{2 実験方法}

実験に用いた磁性粉末は住友特殊金属(侏)のストロンチウム系 フェライト粉末で，焼結助剤として 0.89 mass $\% \mathrm{CaCO}_{3}$ と 0.40 mass $\% \mathrm{SiO}_{2}$ が配合されている.この原料粉末の平均粒径は $0.75 \mu \mathrm{m}$ である。

インナーとアウターの成形圧力 $\sigma_{\mathrm{i}}, \sigma_{\mathrm{o}}$ は，それぞれ $\sigma_{\mathrm{i}}=$ $300 \mathrm{MPa}, \sigma_{0}=100 \mathrm{MPa}$ とした，原を的よりも低くしたのは，焼 結収縮に伴う焼きばめ効果を期待したためである。しかし， フェライト粉末の焼結緻密化の度合いは，Fig.3から分かるよ うに50MPa 程度以上では成形圧力を変えてもさほどの変化は なく,上記の成形圧力では余り高い接合強度は得られないと考 えられる，接合強度を高めるためには $\sigma_{0} を 50 \mathrm{MPa}$ 以下に設定 


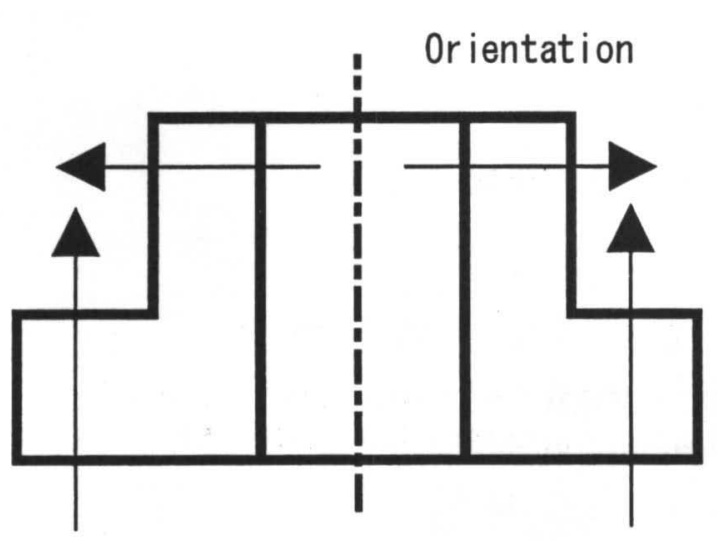

Fig.1 Magnet having a complicated magnetic orientation.

することが望ましいと考えられるが，その一方で，フェライ 卜圧粉体は脆いために $\sigma_{0}$ を低くしすぎると組立が困難になる. そこで本研究では, 原料粉末に $\mathrm{CuO}$ や $\mathrm{CaO}$ の粉末を 0.50 $0.75 \mathrm{mass} \%$ 添加し，インナーとアウターの寸法収縮の差をよ り大きくする方法を試みた.

本実験での添加剤の配合割合と配合の組み合わせを(イン ナー, アウター)の順に示すと, 以下の 3 種類である

No. 1 ; ( 原料粉末のみ, 原料粉末のみ)

No.2; (原料粉末のみ, 0.50 mass\% $\mathrm{CuO}$ 添加)

No.3; (0.75mass\%CaO 添加, $0.75 \mathrm{mass} \% \mathrm{CuO}$ 添加) また,アウターには成形助剤として 5.0 mass\%のポリビニルア ルコール水溶液を, フェライト粉末 $6.0 \mathrm{~g}$ に対して $0.5 \mathrm{~cm}^{3}$ の割 合で加えた。

円柱状インナーを成形するには直径 $\mathrm{d}_{\mathrm{i}}$ が $\phi 11.00 \pm 0.01 \mathrm{~mm}$ の超硬合金製金型を, リング状アウターを成形するには内径 $\mathrm{d}_{0 \mathrm{i}} \times$ 外径 $\mathrm{d}_{00}$ が $(\phi 11.08 \pm 0.01 \mathrm{~mm}) \times(\phi 20.00 \pm 0.01 \mathrm{~mm})$ の超硬 合金製金型を用いた．したがってアウター内径 $\mathrm{d}_{\mathrm{oi}}$ とインナー 直径 $\mathrm{d}_{\mathrm{i}}$ との両側クリアランス $\Delta \mathrm{e}\left(=\mathrm{d}_{\mathrm{oi}}-\mathrm{d}_{\mathrm{i}}\right)$ は $0.08 \mathrm{~mm}$ で, これ をインナー直径 $\mathrm{d}_{\mathrm{i}}$ との比で表すと $\Delta \mathrm{e} / \mathrm{d}_{\mathrm{i}}=0.0073$ である. なお,

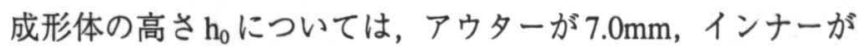
$16.0 \mathrm{~mm}$ になるように粉末重量を調節した。

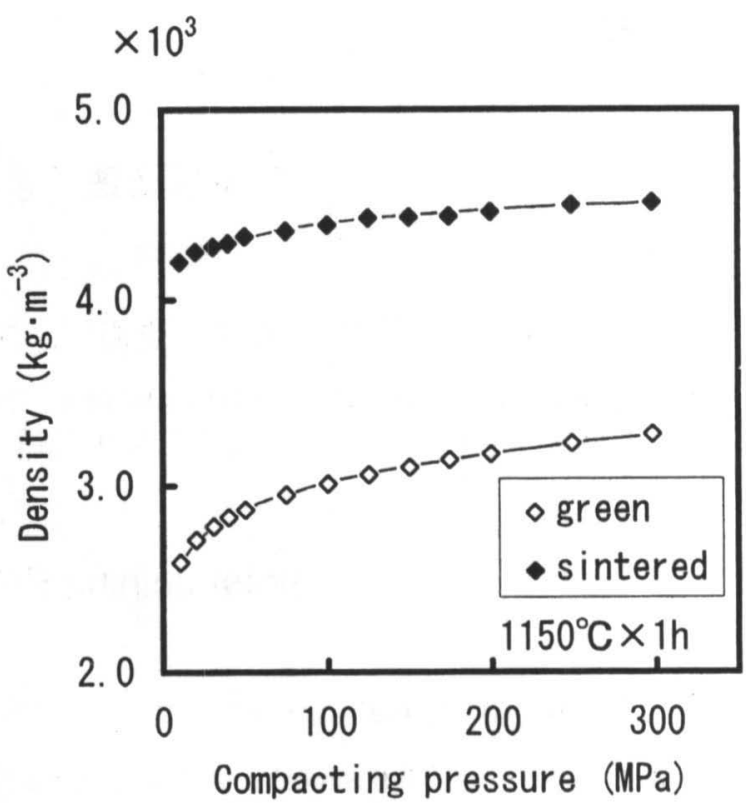

Fig.3 Effect of compacting pressure on density of green and sintered compacts prepared with raw powder.

焼結 (焼成) は大気中で $360^{\circ} \mathrm{C} / \mathrm{h}$ で昇温し, $1150^{\circ} \mathrm{C}$ または $1225^{\circ} \mathrm{C}$ の 2 種類の温度で $1 \mathrm{~h}$ 保持した後, 炉冷するという手順 で行った。

接合強度 $\tau_{\mathrm{s}}$ はせん断試験によって, $\tau_{\mathrm{s}}=\mathrm{P}_{\max } /\left(\pi \times \mathrm{D}_{\mathrm{i}} \times \mathrm{H}_{\mathrm{i}}\right)$ $[\mathrm{MPa}]$ から求めた。 ここで, $\mathrm{P}_{\max }$ は接合強度試験における最大 荷重, $\mathrm{D}_{\mathrm{i}}$ と $\mathrm{H}_{\mathrm{i}}$ は焼結接合体のインナー直径と接合面の高さで ある。

\section{3 実験結果および考察}

3.1 焼結時の収縮率 $\varepsilon_{\theta}$ およびその差 $\Delta \varepsilon_{\theta}$

まず, Fig.4に原料粉末のみで作製したインナーの成形圧力 と焼結による直径の収縮率 $\varepsilon_{\theta}=1 \ln \left(\right.$ 焼結体直径 $\mathrm{D}_{\mathrm{i}}$ ) / (圧粉体 直径 $\mathrm{d}_{\mathrm{i}}$ )।との関係について示した. Fig.3の説明でも触れたよ うに，接合強度を高めるためには， $\sigma_{\mathrm{i}} を \sigma_{0}$ よりも高く設定す

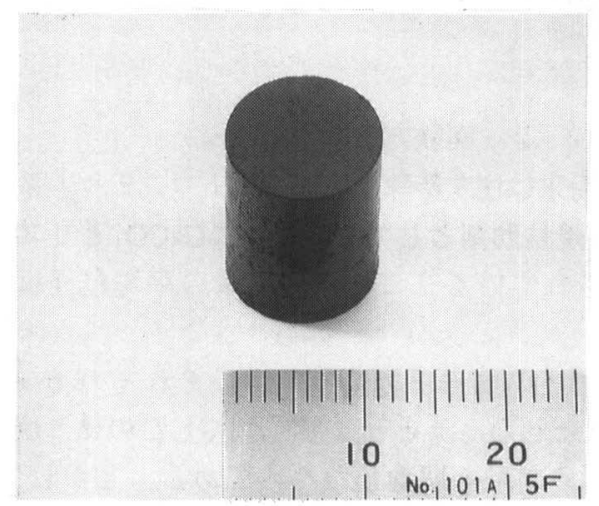

(a) Disk green compact

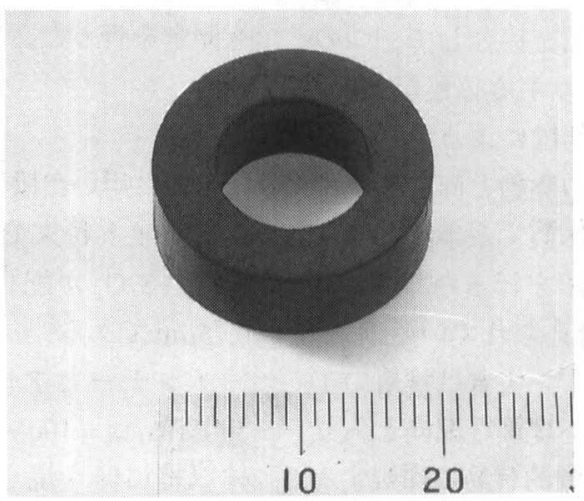

(b) Ring green compact

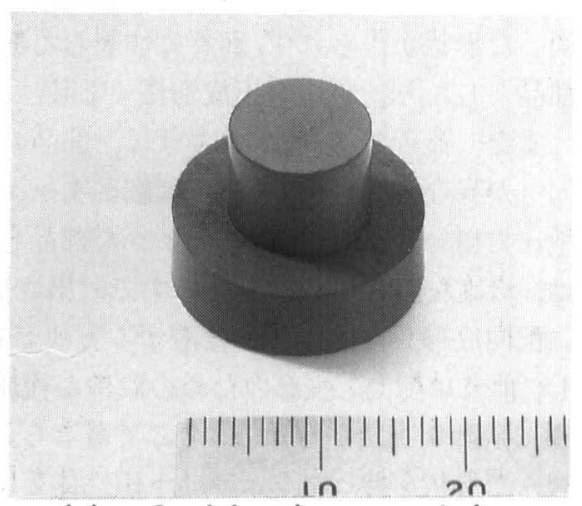

(c) Combined compact by sinter joining

Fig.2 Shape of green compacts and sinter joined compact. 


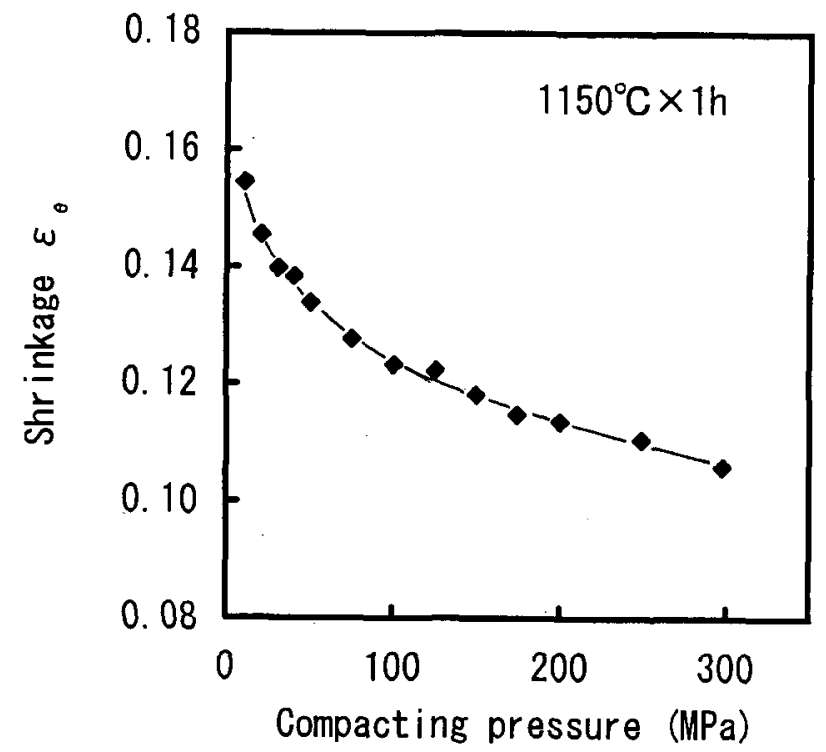

Fig.4 Dependence of compacting pressure on shrinkage $\varepsilon_{\theta}$ of raw powder compact sintered at $1150^{\circ} \mathrm{C}$ for $1 \mathrm{~h}$.

るなどして,アウターとインナーの $\varepsilon_{\theta}$ の差, すなわち $\Delta \varepsilon_{\theta}$ を大 きくする必要がある．しかし，例えば $\sigma_{i}=300 \mathrm{MPa}, \sigma_{0}=50 \mathrm{MPa}$ で成形したとしても $\Delta \varepsilon_{\theta}$ は Fig.4より， $\Delta \varepsilon_{\theta}=\varepsilon_{\theta \mid \sigma_{0}=50}-\varepsilon_{\theta \mid \sigma_{i}=300}=$ 0.028 に過ぎない，そのため，成形圧力に差を設けるだけでは 接合強度の向上に及ほすす効果が薄いと判断される。そこで， 本実験では添加剂の使用を考えた。

Fig.5(a),(b)には，各種の添加剂が焼結体密度と $\varepsilon_{\theta} に$ 及はす 影響について示した，本実験の場合， $\mathrm{CuO}$ 添加では焼結体が 緻密化し, 逆に $\mathrm{CaO}$ 添加は緻密化を緩和する傾向にある。こ の二つの図を参考にしてNo.1〜No.3の配合割合を決定した. また，Fig.5には $\mathrm{SiO}_{2}$ を配合した場合についてもデータがプ ロットされている.グラフから判断すると、より高い $\Delta \varepsilon_{\theta}$ を得 るためには，インナーにCaOを添加するよりも $\mathrm{SiO}_{2}$ を添加し た方が有効であると考えられる，しかし， $\mathrm{SiO}_{2}$ を用いて組み 合わせ焼結を行うと，アウターにFig.6のようなクラックが 生じることが多かったため，今回は使用を見送った，

\section{2 接合強度}

No.1〜No.3の条件で作製した接合体について接合強度試験 を行った結果をTable 1 に示す. Table 1 を見ると, 接合強度の

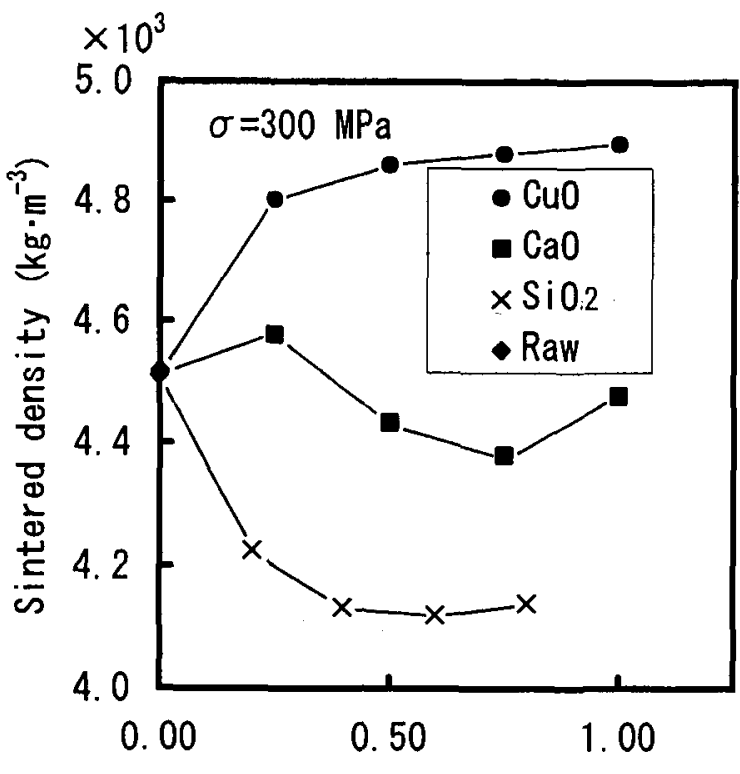

Addition agent (mass\%)

(a) Sintered density

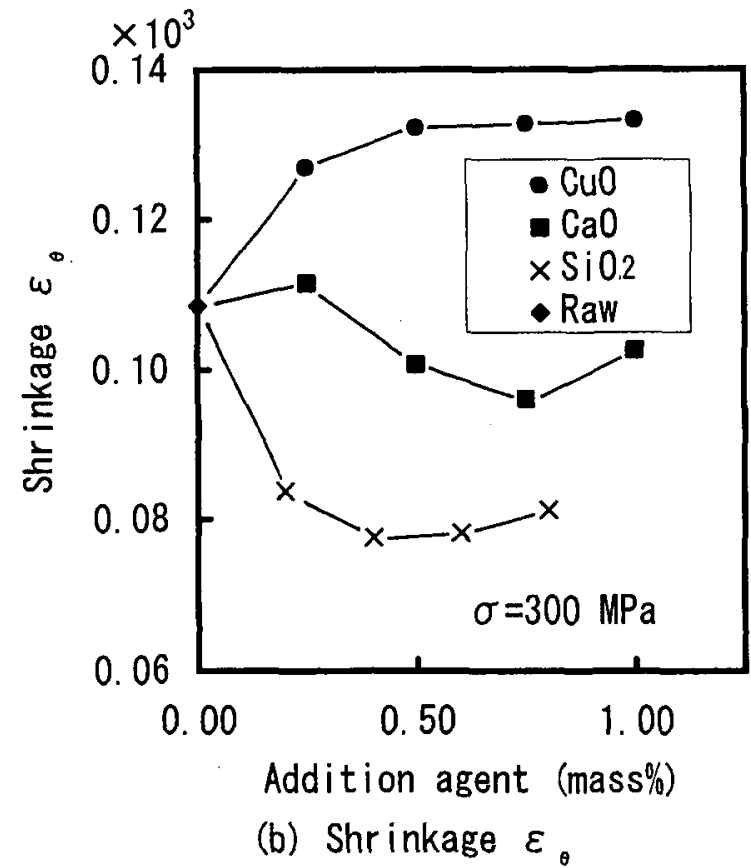

Fig.5 Variation in density and shrinkage of compact with addition agent sintered at $1150^{\circ} \mathrm{C}$ for $1 \mathrm{~h}$.

Table 1 Joint strength obtained from sinter joining of ferrite powder compact.

\begin{tabular}{|c|c|c|c|c|c|c|}
\hline \multirow{3}{*}{ No. } & \multicolumn{2}{|c|}{ Combination } & \multirow{2}{*}{\multicolumn{2}{|c|}{$\begin{array}{c}\text { Shrinkage gap } \\
\Delta \varepsilon_{\theta}\end{array}$}} & \multirow{2}{*}{\multicolumn{2}{|c|}{$\begin{array}{c}\text { Joint strength } \\
/ \mathrm{MPa} \\
\end{array}$}} \\
\hline & \multirow{2}{*}{$\begin{array}{c}\text { Inner, } 300 \mathrm{MPa} \\
\text { /Addition agent } \\
\text { mass } \%\end{array}$} & \multirow{2}{*}{$\begin{array}{c}\text { Outer, } 100 \mathrm{MPa} \\
\text { /Addition agent } \\
\text { mass } \%\end{array}$} & & & & \\
\hline & & & $1150^{\circ} \mathrm{C}$ & $1225^{\circ} \mathrm{C}$ & $1150^{\circ} \mathrm{C}$ & $1225^{\circ} \mathrm{C}$ \\
\hline 1 & Raw powder & Raw powder & 0.0172 & 0.0241 & 4.6 & 12.5 \\
\hline 2 & Raw powder & $0.50 \mathrm{CuO}$ & 0.0546 & 0.0306 & 9.5 & 13.2 \\
\hline 3 & $0.75 \mathrm{CaO}$ & $0.75 \mathrm{Cu} 0$ & 0.0503 & 0.0353 & 11.9 & 20.3 \\
\hline
\end{tabular}




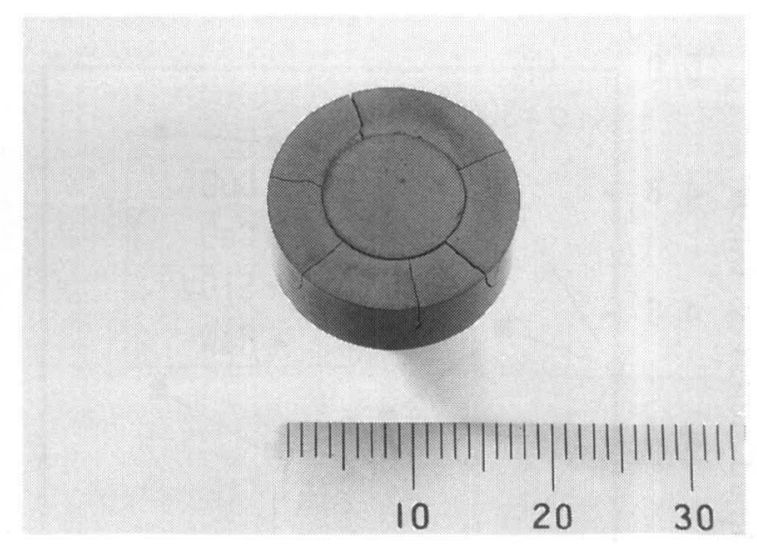

Fig.6 Appearance of crack occurred in outer ring after sintering.

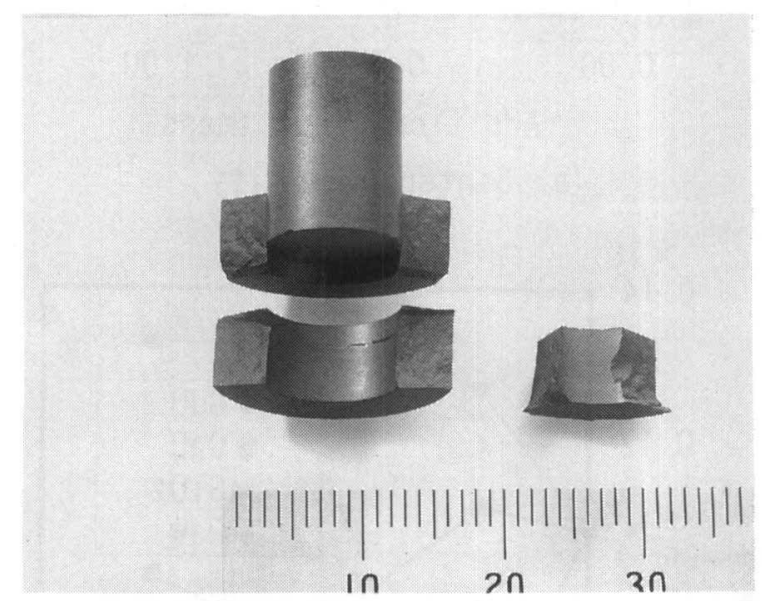

(a) Low strength

(Joint strength $=4$. 6MPa)

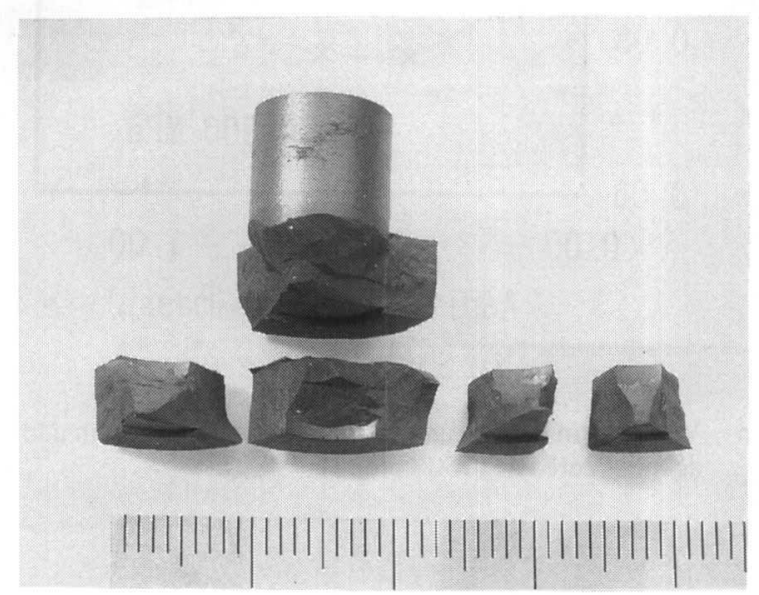

(b) High strength

(Joint strength $=20.3 \mathrm{MPa}$ )

Fig.7 Appearance of joined compacts after strength test.

向上に添加剤の使用が有効であることが分かる. 同じ焼結温 度では, No.3のインナーに $\mathrm{CaO}$ を, アウターにCuOをそれぞ れ $0.75 \mathrm{mass} \%$ 添加した場合が最も高い接合強度を示した．原 料粉末のみで作製したNo.1の接合体と比較すると, $1150^{\circ} \mathrm{C}$ 焼

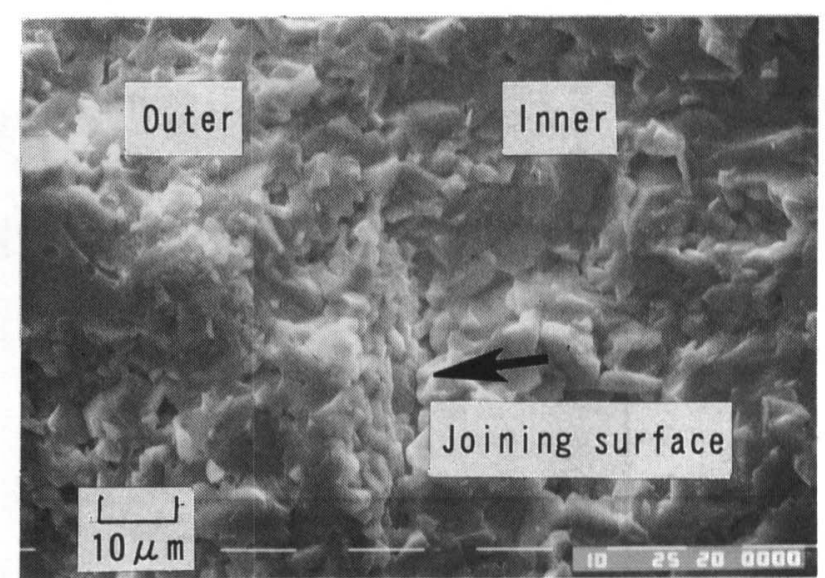

Fig.8 SEM fractograph of joined surface after strength test.

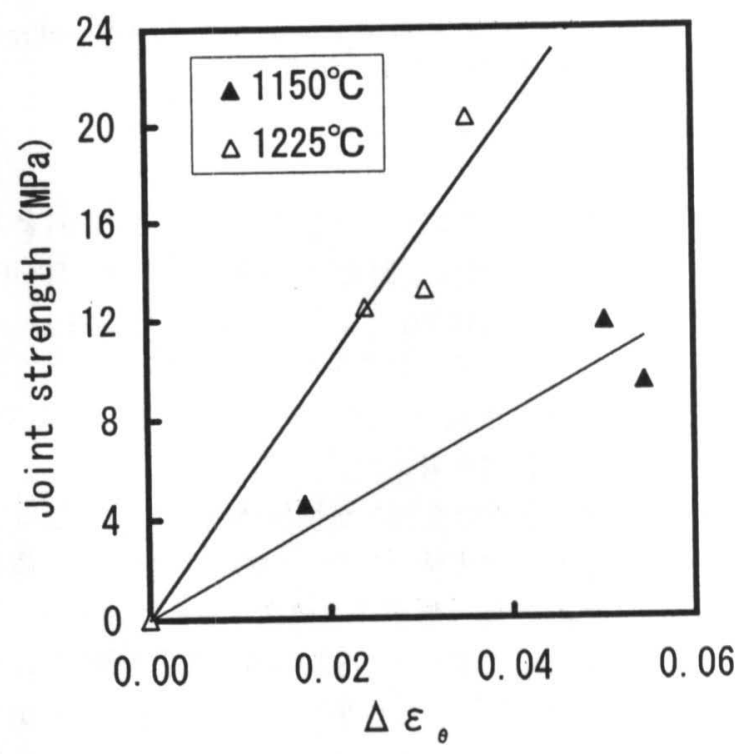

Fig.9 Dependence of shrinkage gap $\Delta \varepsilon_{\theta}$ of compact on joint strength $\left(\Delta \varepsilon_{\theta}=\varepsilon_{\theta_{0}}-\varepsilon_{\theta_{0}}\right)$.

結で 2.6 倍, $1225^{\circ} \mathrm{C}$ 焼結で 1.6 倍の強度向上である. アウター にCuOを $0.50 \mathrm{mass} \%$ 添加した No.2の接合強度は, No.1 と No.3 の中間であった.

Fig.7は接合体の強度試験後の外観を示したものである. 接 合強度が劣る場合がFig.7(a), 強度が大きい場合がFig.7(b)で, 破壊は接合面で生じるものと母材部で生じるものがあった. Fig.8はFig.7(b)の試験片の接合部を SEMで観察したものであ るが, 接合部で拡散が生じていることが分かる.

接合体を実用的な分野に用いるためには，最低でも $10 \mathrm{MPa}$ の接合強度が必要であると考えられる. 本実験の結果は原料 粉末同士を用いたNo.1の場合においても一応, この目標をク リアしているが, 広い分野に応用するためには, 更に強度を 高める研究が必要と思われる.

次に, 接合強度を添加剂の有無に関わりなく $\Delta \varepsilon_{\theta}$ との関係と してグラフにまとめたものが Fig.9である. Fig.9より， $\Delta \varepsilon_{\theta}$ の 
Table 2 Magnetic characteristics of sintered compact (Compacting pressure=300MPa).

\begin{tabular}{|l|c|c|c|c|c|}
\hline $\begin{array}{l}\text { Addition } \\
\text { agents } \\
\text { mass } \%\end{array}$ & $\begin{array}{c}\text { Sinter ing } \\
\text { temp. } \\
/{ }^{\circ} \mathrm{C}\end{array}$ & $\begin{array}{c}\text { Sintered } \\
\text { density } \\
/ \times 10^{3} \mathrm{~kg} \cdot \mathrm{m}^{-3}\end{array}$ & $\begin{array}{c}\text { Residual flux } \\
\text { density } \\
\mathrm{B} r / \mathrm{T}\end{array}$ & $\begin{array}{c}\text { Maximum energy } \\
\text { product } \\
(\mathrm{BH}) \max / \mathrm{kJ} \cdot \mathrm{m}^{-3}\end{array}$ & $\begin{array}{c}\text { Coercive } \\
\text { force } \\
\mathrm{HcJ} / \mathrm{kA} \cdot \mathrm{m}^{-1}\end{array}$ \\
\hline Raw pow. & 1150 & 4.56 & 0.254 & 11.1 & 254 \\
$0.50 \mathrm{Cu0}$ & 1150 & 4.89 & 0.277 & 12.6 & 231 \\
$0.75 \mathrm{CuO}$ & 1150 & 4.91 & 0.278 & 12.3 & 225 \\
$0.75 \mathrm{Ca0}$ & 1150 & 4.57 & 0.254 & 11.1 & 220 \\
\hline Raw pow. & 1225 & 4.91 & 0.280 & 13.4 & 261 \\
$0.50 \mathrm{CuO}$ & 1225 & 4.98 & 0.280 & 12.0 & 199 \\
$0.75 \mathrm{CuO}$ & 1225 & 4.98 & 0.277 & 11.0 & 183 \\
$0.75 \mathrm{CaO}$ & 1225 & 4.85 & 0.276 & 12.8 & 171 \\
\hline
\end{tabular}

大きい条件で作製した接合体の方が，接合強度が高くなると いう傾向にあることが分かる，焼結温度による影響も顕著に 現れており，同じ $\Delta \varepsilon_{\theta}$ では $1225^{\circ} \mathrm{C}$ で烵結した接合体の方が $1150^{\circ} \mathrm{C}$ で焼結した接合体の 2 倍近い強度を示した。

本実験においてはフェライト圧粉体の脆さのために，組立 に注意を要する場合があった。これに対して，著者らはイン ナーを $750 \sim 1000^{\circ} \mathrm{C}\left(\varepsilon_{\theta}=9.0 \times 10^{-4} \sim 1.4 \times 10^{-2}\right)$ で予備焼結し， 少し収縮させてから組立を行ったり，接合面のクリアランス を $0.08 \mathrm{~mm}$ から $0.25 \mathrm{~mm}$ に広げるなどの対応策を試みた。しか し，前者の方法では焼結後アウター部にFig.6で示したような クラックが見られることが多く，後者の方法ではクリアラン スが大きすぎたためにほとんど接合強度が得られなかった。 このため，今後は適正なクリアランスを模索すると共に，成 形体の強度を高めるための研究も予定している。

接合体に強度をもたらす要因としては，インナー・アウ ターの焼結時における熱膨張の挙動中.5や母材強度なども考慮 する必要があるが, 当面は今回述べた収縮率の差 $\Delta \varepsilon_{\theta}$ の観点か ら研究を進める方針である.

現在は，インナー成形体を配向してから組み合わせ焼結を 行い，部位によって異なる配向を得ると同時に，配向による 焼結寸法の異方性を利用して接合強度の向上を図る研究に着 手している。その他にも，(1) 磁性粉末にMIM 用の熱分解性 バインダを加えて，圧粉体の強度向上と焼結による緻密化を 促進させる，(2)本実験では用いなかった $\mathrm{SiO}_{2}$ をンナーに配 合して,クラックの生じないようなクリアランスでの焼結接 合を行うなどの手段を考えている.

3.3 焼結体の磁気特性の評価

焼結体の残留磁束密度 $\mathrm{B}_{r}$, 最大エネルギ皘 $(\mathrm{BH})_{\max }$ および保 磁力 $\mathrm{H}_{c J}$ の測定結果を Table 2 に表す。原料粉末は $\mathrm{B}_{r},(\mathrm{BH})_{\max }$ お よび $\mathrm{H}_{c J}$ のバランスがよく，特に $1225^{\circ} \mathrm{C}$ 焼結において良好で ある。一方，接合強度を高めるために $\mathrm{CuO}$ と $\mathrm{CaO}$ を添加した 場合には てそん色ないが，保磁力 $\mathrm{H}_{c}$ が低下しその度合いは $1150^{\circ} \mathrm{C}$ よ りも $1225^{\circ} \mathrm{C}$ 焼結の方が大きい.したがって用途によっては接
合強度を向上させるために $\mathrm{CuO}$ と $\mathrm{CaO}$ を添加するとよいが， 保磁力が低下することに注意しなければならない．

\section{4 結言}

クリアランス比が $\Delta \mathrm{e} / \mathrm{d}_{\mathrm{i}}=0.0073$ の一定条件の下で, ストロン チウム系フェライト粉末圧形体の組み合わせ焼結接合を行い, 接合強度と磁気特性を検討した。得られた結果は以下の通り である。

1）原料粉末のみで作製した接合体においても $1225^{\circ} \mathrm{C}$ 焼結で 12.5MPaの強度が得られたが, $\mathrm{CuO}$ と $\mathrm{CaO}$ を添加すること により20.3MPaに向上させることができた。しかし，これ らを添加すると保磁力が低下するので, 用途によっては強 度と保磁力のバランスを考慮することが必要である。

2）接合強度を向上させるためには,インナー・アウター間に おける焼結時の収縮率の差; $\Delta \varepsilon_{\theta}$ を高めることが，一つの 有効な手段である.

3） $\Delta \varepsilon_{\theta}$ を高めるためには，インナーとアウターの成形圧力を 変えるだけでは不十分で， $\mathrm{CuO} や \mathrm{CaO}$ などの添加郕を併 用すると効果的である。

4）成形条件が同じ場合には，焼結温度を高くした方が接合強 度は大きくなる，具体的には焼結温度を $1150^{\circ} \mathrm{C}$ から $1225^{\circ} \mathrm{C}$ に高めると，接合強度は $1.4 \sim 2.7$ 倍に增加した。

\section{謝 辞}

最後に，本研究の実験に協力していただいた摄南大学工学 部機械工学科 1996 年度卒業研究生山田誉治君, 1997 年度卒 業研究生 加島孝彦君と山本浩史君 (当時)に感謝します。

\section{文献}

1）例えば山下治: "金属射出成形で作製したNd-Fe-B 磁石の 磁気特性", 粉体および粉末治金, 42(1995)1073-1078.

2）安保武志, 元根隆博: "制御用モーターの界磁用プラスチッ ク磁石 ", 特公平 5-37330, (1993.6.2)35-41.

3) T.Tabata, S.Masaki, H.Suzuki and B.Q.Zhu: "Bond strength of 
sintered bonded composite preforms", Int. J. Powder Metall., 25 (1989)37-41.

4）浅香一夫: "焼結に上る鉄系圧粉体の拡散接合(第3 報) 拡 散接合に及ぼす鉄粉の種類の影響", 粉体および粉末治金, 44(1997)374-380.

5）浅香一夫, 加賀谷剛：“焼結による鉄系圧粉体の拡散接合 (第4 報) SUS304 圧粉体の焼結拡散接合", 粉体および粉末
治金, 44(1997)751-756.

6）真崎才次，沖本邦郎，小西政成："焼結接合法によるセラ ミック部品の製作", 塑性と加工, 36(1995)1331-1336.

7) 沖本邦郎, 和泉克尚, 佐藤富雄, 加藤䣄之: "粉末治金法に よるステンレス鋼/パーマロイ複合材の製作における粉末 粒径の影響", 粉体粉末治金協会平成 9 年度春期大会概要集 (1997)161. 